\title{
Pola makan makanan kariogenik dan non kariogenik serta pengalaman karies anak usia 11-12 tahun di SDN Cikawari Kabupaten Bandung
}

\author{
Dela Armilda $^{1}$, Dudi Aripin ${ }^{1 *}$, Inne Suherna Sasmita ${ }^{2}$ \\ ${ }^{1}$ Departemen Konservasi Gigi, Fakultas Kedokteran Gigi, Universitas Padjadjaran, Indonesia \\ ${ }^{2}$ Departemen Pedodonsia, Fakultas Kedokteran Gigi, Universitas Padjadjaran, Indonesia
}

*Korespondensi: dudi.aripin@fkg.unpad.ac.id

\begin{abstract}
ABSTRAK
Pendahuluan: Karies merupakan penyakit infeksi yang disebabkan oleh demineralisasi email dan dentin serta erat hubungannya dengan makanan kariogenik. Umumnya anak usia sekolah dasar memiliki kebiasaan makan makanan kariogenik yang bersifat lengket dan mudah hancur di dalam mulut sehingga dapat meningkatkan risiko karies. Tujuan penelitian ini adalah untuk mengetahui gambaran distribusi pola makan makanan kariogenik dan non kariogenik serta pengalaman karies pada anak usia 11-12 tahun di SDN Cikawari, Kabupaten Bandung. Metode: Jenis penelitian deskriptif dengan desain penelitian cross sectional. Sampel penelitian ini berjumlah 41 anak dengan menggunakan teknik purposive sampling. Instrumen penelitian yang digunakan adalah: Food Frequency Questionaire, formulir DMF-T, alat tulis, instrumen dasar pemeriksaan gigi dan mulut, cahaya senter, dan alat pelindung diri standar. Hasil: Persentase tertinggi pola makan makanan kariogenik adalah snack $(46,13 \%)$, roti $(43,9 \%)$ dan permen $(41,46 \%)$. Persentase tertinggi pola makan makanan non kariogenik adalah nasi $(70,73 \%)$, sayuran $(48,78 \%)$, dan mie instan $(43,9 \%)$ serta rerata indeks DMF-T adalah 3,95. Simpulan: Distribusi pola makan makanan kariogenik tertinggi pada anak usia 11-12 tahun di SDN Cikawari, Kabupaten Bandung, adalah snack, roti dan permen, serta distribusi pola makan makanan non kariogenik tertinggi adalah nasi, sayuran dan mie instan. Pengalaman karies menunjukkan rerata indeks DMF-T yang termasuk kategori sedang.
\end{abstract}

Kata kunci: Pola makan makanan kariogenik, pola makan makanan non kariogenik, pengalaman karies anak.

\section{The cariogenic and non cariogenic food dietary patterns with dental caries experience of 11-12 years old children at SDN Cikawari Kabupaten Bandung}

\begin{abstract}
Introduction: Dental caries is an infectious disease caused by demineralization of email and dentin which are associated with cariogenic food. Generally, school-age children have dietary patterns that prefer to cariogenic food which is sticky and easily melt in the mouth so that can increase the caries risk. The purpose of this study was to determine the distribution of cariogenic food dietary patterns, non cariogenic food dietary patterns and dental caries experience of 11-12 years old children in SDN Cikawari Kabupaten Bandung. Methods: The method of this study was descriptive with cross sectional design. The sample of this study were 41 children which using purposive sampling technique. The research instruments used were: Food Frequency Questionnaire, DMF-T form, stationery, basic instruments of dental and oral examination, flashlight, and standard self protective equipment. Results: The highest percentage of cariogenic food dietary patterns was snack $(46,13 \%)$, bread (43,9\%) and candies $(41,46 \%)$. The highest percentage of non cariogenic food dietary patterns was rice $(70,73 \%)$, vegetables (48,78\%), and instant noodles (43,9\%). The average of DMF-T index at 3,95. Conclusion: The highest distribution of cariogenic food dietary patterns is snack, bread and candies with the highest distribution of non cariogenic food dietary patterns is rice, vegetables and instant noodles. Dental caries experience shows that the average of DMF-T index is moderate.
\end{abstract}

Keywords: Cariogenic food dietary patterns, non cariogenic food dietary patterns, dental caries experience in children. 


\section{PENDAHULUAN}

Usia sekolah merupakan salah satu tahapan kehidupan yang dialami oleh seseorang, salah satunya adalah tahapan anak sekolah dasar yang berusia 6-12 tahun. ${ }^{1}$ Anak pada usia ini masih mengalami tahap pertumbuhan disertai aktifitas fisik yang meningkat, seperti bermain dan berolahraga. Pertumbuhan anak usia sekolah tersebut akan optimal jika nutrisi yang diberikan memiliki kualitas yang baik serta kuantitas yang memadai. ${ }^{2}$ Pemberian nutrisi atau asupan makanan anak pada masa pertumbuhan ini tidak selalu dapat dilaksanakan dengan sempurna sehingga sering timbul masalah, terutama akibat pemberian makanan yang menyimpang dan tidak benar. $^{3}$

Asupan zat gizi pada anak sekolah sangat dipengaruhi oleh kebiasaan makan. Kebiasaan makan yang salah pada anak sekolah dasar sering terjadi, seperti kebiasaan mengkonsumsi makanan secara berlebihan. Makanan yang sering dikonsumsi anak sekolah dasar banyak bersifat kariogenik. Makanan kariogenik merupakan makanan yang banyak mengandung gula, seperti makanan manis, lengket, serta makanan yang berbentuk menarik yang dapat menyebabkan karies pada gigi. Hal ini disebabkan makanan kariogenik memiliki kecenderungan untuk melekat pada permukaan gigi. ${ }^{2}$

Karies gigi merupakan penyakit infeksi yang disebabkan oleh demineralisasi email dan dentin yang erat hubungannya dengan konsumsi makanan kariogenik. $^{4}$ Anak-anak usia sekolah dasar biasanya mengkonsumsi makanan kariogenik yang mengandung sukrosa lebih dari 3 kali sehari. Peningkatan frekuensi konsumsi makanan kariogenik ini akan menyebabkan keberadaan $\mathrm{pH}$ yang rendah di dalam mulut dipertahankan sehingga terjadi peningkatan demineralisasi dan penurunan remineralisasi. ${ }^{5}$ Ketidakseimbangan proses demineralisasi dan remineralisasi inilah yang berujung pada karies. Secara umum keadaan kebersihan mulut pada anak lebih buruk karena anak lebih banyak makan makanan dan minuman yang menyebabkan karies dibanding orang dewasa. ${ }^{5}$ Pola makan makanan kariogenik baik jenis, cara mengkonsumsi, waktu, dan frekuensi mengkonsumsi makanan kariogenik yang berlebih juga diduga dapat meningkatkan risiko terjadinya karies gigi pada anak. $^{6}$
Menurut Hasil Riset Kesehatan Dasar tahun $2013^{7}$, sebesar 30\% penduduk Indonesia mempunyai masalah gigi dan mulut. Survei Departemen Kesehatan Republik Indonesia tahun 2010 menunjukkan bahwa prevalensi penduduk Indonesia yang menderita karies gigi sebesar $80 \%$ $90 \%$ dan diantaranya adalah golongan anak, angka prevalensi pengalaman karies penduduk usia 12 tahun di Indonesia sebesar 36,1\% dengan karies aktif sebanyak 29,8\%.7 Penelitian Indry Worotitjan, dkk. $^{8}$ yang dilaksanakan pada anak Sekolah Dasar di Desa Kiawa Kecamatan Kawangkoan Utara tahun 2013 menunjukkan anak sekolah dasar yang menjadi responden memiliki karies gigi kategori sedang dengan jumlah rerata DMF-T, yaitu 3,71 serta pola makan makanan karbohidrat kariogenik tertinggi yaitu snack dengan frekuensi konsumsi 2-3 kali per hari. $^{8}$

Penelitian Hidayanti ${ }^{9}$ yang dilakukan pada anak Sekolah Dasar di Kecamatan Cihideung Kota Tasikamalaya tahun 2005 menunjukkan adanya hubungan kebiasaan konsumsi makanan kariogenik, makanan pencegah karies dan skor konsumsi makan dengan keparahan karies gigi. Rerata konsumsi makanan kariogenik sebesar $12,6 \pm 4,5$ dan rerata indeks def-t sebesar 5,93 $\pm 3,13 .{ }^{9}$ Penelitian Rosidi ${ }^{6}$ pada tahun 2003 yang dilakukan pada anak SDN I Gogodalem, Kecamatan Bringin, Kabupaten Semarang, juga menunjukkan adanya hubungan yang signifikan antara konsumsi makanan kariogenik dengan kejadian gigi pada responden yang diteliti dengan nilai uji Chi Square sebesar 0,000 dan p-value 0,000 . Sebagian besar tingkat konsumsi makanan kariogenik pada anak di SDN 1 Gogodalem, dalam kategori tinggi yaitu sejumlah 40 anak $(85,1 \%)$. Kejadian karies dialami oleh sebagian besar anak gigi pada anak SDN 1 Gogodalem dengan angka yang sama, yaitu sejumlah 40 anak $(85,1 \%){ }^{6}$

SDN Cikawari merupakan salah satu sekolah dasar negeri yang terletak di Kecamatan Cimenyan Kabupaten Bandung. Banyak makanan yang bersifat kariogenik dijumpai dijual di sekitar lokasi SDN Cikawari Kabupaten Bandung ini, dan banyak anak yang memiliki kebiasaan mengkonsumsi makanan tersebut. Sejauh ini belum pernah dilakukan penelitian mengenai distribusi pola makan makanan kariogenik dan non kariogenik serta pengalaman karies pada anak usia 11-12 tahun di SDN Cikawari, Kabupaten Bandung. Pemilihan anakusia 11-12 tahun 
karena berdasarkan $\mathrm{WHO}^{10}$, usia 12 tahun ditetapkan sebagai usia pemantauan global (global monitoring age) untuk karies. ${ }^{10}$ Berdasarkan uraian tersebut, tujuan penelitian ini adalah untuk mengetahui distribusi pola makan makanan kariogenik dan non kariogenik serta pengalaman karies pada anak usia 11-12 tahun SDN Cikawari, Kabupaten Bandung.

\section{METODE}

Jenis penelitian yang dilakukan merupakan jenis penelitian deskriptif dengan desain penelitian cross sectional study. Populasi pada penelitian adalah seluruh anak SDN Cikawari Kabupaten Bandung yang berjumlah 192 orang. Sampel penelitian ini berjumlah 41 orang yang diperoleh dengan menggunakan teknik purposive sampling dan telah memenuhi kriteria inklusi dan eksklusi. Purposive sampling adalah metode pengambilan sampel yang dilakukan dengan mengambil sampel orang-orang yang dipilih oleh penulis menurut ciri-ciri spesifik dan karakteristik tertentu. ${ }^{11}$

Lokasi penelitian adalah SDN Cikawari, Kabupaten Bandung. Kriteria inklusi pada penelitian ini, yaitu: (1) siswa berusia 11-12 tahun, (2) bersedia menjadi subjek penelitian dengan mengisi informed consent, dan (3) bersikap kooperatif selama penelitian berlangsung. Kriteria ekslusi pada penelitian ini, yaitu: (1) siswa SDN Cikawari, Kabupaten Bandung yang berusia kurang dari 11 tahun atau lebih dari 12 tahun, (2) siswa SDN Cikawari, Kabupaten Bandung, yang berusia 11-12 tahun namun tidak bersedia menjadi subjek penelitian, (3) berhalangan hadir saat penelitian dilakukan serta (4) siswa memiliki keterbatan mental atau memiliki penyakit sistemik yang menyulitkan pengambilan data saat penelitian berlangsung. Instrumen yang digunakan untuk penelitian ini adalah sebagai berikut: Informed Consent, Food Frequency Questionaire, Formulir pengisian DMF-T, Alat tulis, Instrumen dasar meliputi kaca mulut, sonde, pinset, ekskavator, Wadah instrumen dasar, Alkohol 70\%, Gelas kusia, Senter, Air mineral, Baki, Tisu kering, Sarung tangan, Masker. Variabel pada penelitian ini adalah pola makan makanan kariogenik, pola makan makanan non kariogenik dan pengalaman karies.

Pola makan makanan kariogenik adalah frekuensi konsumsi makan makanan kariogenik yang menyebabkan karies berupa roti, kue, permen, coklat dan snack (makanan ringan) dalam kegiatan makannya per hari yang dapat diketahui melalui Food Frequency Questionnaire. Pola makan makanan non kariogenik adalah frekuensi konsumsi makan makanan non kariogenik yang tidak menyebabkan karies berupa nasi, jagung, mie instan, ubi jalar, singkong, sayuran, kacang-kacangan dan buah buahan dalam kegiatan makannya per hari yang dapat diketahui melalui Food Frequency Questionnaire:

Pengalaman karies adalah terdapatnya karies, kehilangan gigi dan terdapat tambalan gigi karena karies, dinyatakan dalam indeks DMF-T. Indeks DMF-T adalah angka yang dinyatakan untuk menilai keadaan gigi permanen dengan kondisi gigi terdapat bercak cokelat hingga kehitaman atau telah terbentuk lubang karena karies (decayed), dicabut karena karies (missing), dan terdapat tambalan karena karies (filling). Indeks DMF-T didapatkan dengan menjumlahkan gigi decayed (D), missing (M) dan filling (F). Kategori dalam perhitungan indeks DMF-T berdasarkan WHO Oral Basic Health Survey adalah: sangat rendah $(0,0-1,1)$, rendah $(1,2-2,6)$, sedang $(2,7-4,4)$, tinggi $(4,5-6,5)$ dan sangat tinggi $(>6,6)$. Skor rerata DMF-T untuk 41 subyek penelitian ini diukur dengan rumus Rerata DMF-T= Jumlah $\mathrm{D}+\mathrm{M}+\mathrm{F} /$ Jumlah orang yang diperiksa

Orang tua/wali subyek penelitian yang memenuhi kriteria penelitian terlebih dahulu diminta menandatangani lembar informed consent. Selanjutnya dilakukan pengisian Food Frequency Questionnaire oleh peneliti berdasarkan hasil wawancara terhadap subjek penelitian dengan memberi tanda pada daftar makanan kariogenik dan non kariogenik yang tertera pada Food Frequency Questionnaire sesuai dengan frekuensi makanan yang dikonsumsi per hari. Tahap selanjutnya adalah pemeriksaan indeks DMF-T, yaitu subjek penelitian dipersiapkan untuk pemeriksaan, diminta untuk duduk di kursi yang telah disediakan dan bersikap kooperatif selama pemeriksaan indeks DMF-T. Data yang diperoleh kemudian dicatat pada formulir pemeriksaan indeks DMF-T. Peneliti melakukan evaluasi pemeriksaan ulang mengenai indeks DMF-T maupun Food Frequency Questionnaire yang telah diisi.

Data yang diperoleh akan diperiksa ulang melalui proses editing, pemberian kode pada data atau coding dan tabulasi data berdasarkan distribusi frekuensi dan disajikan dalam bentuk tabel serta ditampilkan secara deskriptif berdasarkan persentase. 
HASIL

Penelitian dilakukan dengan pengisian kuesioner oleh 41 siswa SDN Cikawari Kabupaten Bandung yang memenuhi kriteria sampel mengenai pola makan makanan kariogenik dan non kariogenik; pemeriksaan pengalamaan karies dilakukan dengan metode pemeriksaan indeks DMF-T. Hasil penelitian yang didapatkan adalah karakteristik subjek penelitian berdasarkan jenis kelamin dan usia, pola makan makanan kariogenik, pola makan makanan non kariogenik, masing-masing berdasarkan usia; pengalaman karies yang dinyatakan dalam indeks DMF-T berdasarkan komponen DMF-T dan usia. Karakteristik subjek penelitian terdiri dari jenis kelamin, yaitu laki-laki dan perempuan (Tabel 1), serta berdasarkan usia subjek penelitian, yaitu usia 11 dan 12 (Tabel 2).

Tabel 1 menunjukkan bahwa karakteristik subjek penelitian pada siswa SDN Cikawari, Kabupaten Bandung usia 11-12 tahun dengan jumlah subjek 41 anak terdiri dari 20 anak dengan jenis kelamin laki-laki dan 21 anak dengan jenis kelamin perempuan. Hasil penelitian menunjukkan subjek berjenis kelamin perempuan memiliki jumlah lebih banyak (51.22\%) daripada subjek berjenis kelamin laki-laki (48,78\%).

Tabel 1. Karakteristik subjek penelitian berdasarkan jenis kelamin

\begin{tabular}{ccc}
\hline Jenis Kelamin & Jumlah (n) & Persentase (\%) \\
\hline Laki-laki & 19 & 46,34 \\
Perempuan & 22 & 53,66 \\
\hline Total & $\mathbf{4 1}$ & $\mathbf{1 0 0}$ \\
\hline
\end{tabular}

Tabel 2. Karakteristik subjek penelitian berdasarkan usia

\begin{tabular}{ccc}
\hline Usia & Jumlah (n) & Persentase (\%) \\
\hline 11 & 22 & 53,66 \\
12 & 19 & 46,34 \\
\hline Total & $\mathbf{4 1}$ & $\mathbf{1 0 0}$ \\
\hline
\end{tabular}

Tabel 2 terdapat 22 anak yang berusia 11 tahun dan 19 siswa yang berusia 12 tahun. Hasil penelitian menunjukkan siswa yang berusia 11 tahun memiliki jumlah yang lebih banyak $(53,66 \%)$ daripada yang berusia 12 tahun $(46,34 \%)$.

Tabel 3 menunjukkan bahwa pengalaman karies gigi pada 41 siswa SDN Cikawari Kabupaten Bandung Kecamatan Cimenyan Kabupaten Bandung yang berusia 11-12 tahun memiliki jumlah DMF-T 162 dengan rerata DMF-T 3,95. Hasil rerata ini menunjukkan subjek penelitian termasuk dalam pengalaman karies kategori sedang.

Tabel 4 menunjukkan tiga persentase tertinggi yaitu pada pola makan nasi 2-3 kali sehari yang dimiliki oleh 29 anak (70,73\%), pola makan sayuran yang dikonsumsi 2-3 kali sehari pada 20 anak $(48,78 \%)$ serta pola makan mie instan yang dikonsumsi satu kali sehari oleh 18 anak (43,90\%). Persentase pola makan terkecil terdapat pada frekuensi pola makan nasi 1 kali sehari dengan jumlah 2 anak (4,87\%).

Hasil penelitian mengenai pola makan makanan kariogenik pada siswa SDN Cikawari, Kabupaten Bandung, seperti tertera pada tabel 5, menunjukkan tiga persentase pola makan makanan kariogenik tertinggi adalah pola makan snack yang dikonsumsi lebih dari tiga kali sehari dengan jumlah anak 19 (46,13\%), pola makan roti yang dikonsumsi satu kali sehari dengan jumlah anak 18 (43,90\%) serta pola makan permen yang dikonsumsi lebih dari tiga kali sehari dengan jumlah anak $(41,46 \%)$. Persentase pola makan makanan kariogenik terendah adalah pola makan roti yang dikonsumsi lebih dari 3 kali sehari dengan jumlah 3 anak $(7,31 \%)$.

Tabel 3. Pengalaman karies masing-masing komponen DMF-T

\begin{tabular}{crrccc}
\hline & DMF-T & & Jumlah & Rerata DMF-T \\
\cline { 1 - 3 } D & M & F & & \\
\hline 161 & 1 & 0 & 162 & 3,95 \\
\hline
\end{tabular}

Tabel 3. Distribusi frekuensi pola makan makanan kariogenik per hari pada anak usia 11-12 Tahun

\begin{tabular}{|c|c|c|c|c|c|c|c|c|c|c|c|c|}
\hline \multirow{3}{*}{$\begin{array}{c}\text { Jenis makanan } \\
\text { kariogenik }\end{array}$} & \multicolumn{6}{|c|}{ Frekuensi pola makan / hari } & \multirow{2}{*}{\multicolumn{2}{|c|}{ Lainnya }} & \multirow{2}{*}{\multicolumn{2}{|c|}{ Tidak pernah }} & \multirow{2}{*}{\multicolumn{2}{|c|}{ Jumlah }} \\
\hline & \multicolumn{2}{|c|}{1 Kali } & \multicolumn{2}{|c|}{ 2-3 Kali } & \multicolumn{2}{|c|}{$>3$ Kali } & & & & & & \\
\hline & $\mathbf{N}$ & $\%$ & $\mathbf{N}$ & $\%$ & $\mathbf{N}$ & $\%$ & $\mathbf{N}$ & $\%$ & $\mathbf{N}$ & $\%$ & $\mathbf{N}$ & $\%$ \\
\hline Roti & 18 & 43.90 & 9 & 21,95 & 3 & 7,31 & 7 & 17,07 & 3 & 7,31 & 41 & 100 \\
\hline Kue & 7 & 17,07 & 13 & 31,7 & 9 & 21,95 & 7 & 17,07 & 5 & 12,19 & 41 & 100 \\
\hline Permen & 9 & 21,95 & 11 & 26,82 & 17 & 41,46 & 3 & 7,31 & 1 & 2,43 & 41 & 100 \\
\hline Coklat & 11 & 26,82 & 8 & 19,51 & 7 & 17,07 & 9 & 21,95 & 6 & 14,6 & 41 & 100 \\
\hline Snack & 6 & 14,68 & 15 & 36,58 & 19 & 46,13 & 1 & 2,43 & 0 & 0 & 41 & 100 \\
\hline
\end{tabular}




\begin{tabular}{|c|c|c|c|c|c|c|c|c|c|c|c|c|}
\hline \multirow{4}{*}{$\begin{array}{c}\text { Jenis Makanan Non } \\
\text { Kariogenik }\end{array}$} & \multicolumn{6}{|c|}{ Frekuensi Pola Makan } & \multirow{3}{*}{\multicolumn{2}{|c|}{ Lainnya }} & \multirow{3}{*}{\multicolumn{2}{|c|}{ Tidak Pernah }} & \multirow{2}{*}{\multicolumn{2}{|c|}{ Jumlah }} \\
\hline & \multicolumn{6}{|c|}{ Hari } & & & & & & \\
\hline & \multicolumn{2}{|c|}{1 kali } & \multicolumn{2}{|c|}{ 2-3 kali } & \multicolumn{2}{|c|}{$>3$ kali } & & & & & \multirow[b]{2}{*}{$\mathbf{n}$} & \multirow[b]{2}{*}{$\%$} \\
\hline & $\mathbf{n}$ & $\%$ & $\mathbf{n}$ & $\%$ & $\mathbf{n}$ & $\%$ & $\mathbf{n}$ & $\%$ & $\mathbf{n}$ & $\%$ & & \\
\hline Nasi & 2 & 4,87 & 29 & 70,73 & 10 & 24,39 & 0 & 0 & 0 & 0 & 41 & 100 \\
\hline Jagung & 15 & 36,58 & 6 & 14,63 & 4 & 9,75 & 10 & 24,39 & 6 & 14,63 & 41 & 100 \\
\hline Mie Instan & 18 & 43,9 & 12 & 29,26 & 3 & 7,31 & 6 & 14,63 & 2 & 4,87 & 41 & 100 \\
\hline Ubi Jalar & 10 & 24,39 & 7 & 17,07 & 4 & 9,75 & 10 & 24,39 & 10 & 24,39 & 41 & 100 \\
\hline Singkong & 10 & 24,39 & 12 & 29,26 & 4 & 9,75 & 8 & 19,51 & 7 & 17,07 & 41 & 100 \\
\hline Sayuran & 9 & 21,95 & 20 & 48,78 & 9 & 21,95 & 3 & 7,31 & 0 & 0 & 41 & 100 \\
\hline Kacang-kacangan & 14 & 34,14 & 13 & 31,7 & 3 & 7,31 & 4 & 9,75 & 7 & 17,07 & 41 & 100 \\
\hline Buah-buahan & 13 & 31,70 & 14 & 34,14 & 8 & 19,51 & 5 & 12,19 & 1 & 2,43 & 41 & 100 \\
\hline
\end{tabular}

\section{PEMBAHASAN}

Hasil penelitian mengenai pola makan makanan kariogenik pada anak usia 11-12 tahun di SDN Cikawari, Kecamatan Cimenyan, Kabupaten Bandung yang ditinjau dari frekuensi makan per harinya, persentase tertinggi terdapat pada pola makan snack dengan frekuensi lebih dari 3 kali sehari berjumlah 19 anak (46,13\%). Kebiasaan makan snack pada anak usia 11-12 tahun ini sejalan dengan penelitian yang dilakukan oleh Worotitjan dkk tahun 2013, yang dilakukan pada anak kelas VI SD di Desa Kiawa, Kecamatan Kawangkoan Utara, yaitu sebanyak 20 anak (33,33\%) dengan frekuensi pola makan snack 2-3 kali sehari. ${ }^{8}$ Snack merupakan salah satu bentuk makanan jajanan yang banyak ditemukan di pinggir jalan yang dijajakan dengan harga yang murah dan dijual dalam berbagai bentuk, warna, ukuran, dan rasa yang sesuai dengan kegemaran anak-anak, yaitu manis, gurih, dan asam sehingga menarik minat dan perhatian untuk membelinya. Kejadian ini sering dimanfaatkan oleh produsen makanan untuk menarik konsumen terutama anakanak. $^{12}$ Berdasarkan pengamatan peneliti, banyak pedagang yang menjual makanan ringan (snack) berupa keripik di sekitar SDN Cikawari, Kabupaten Bandung sehingga memudahkan anak-anak untuk membelinya.

Persentase pola makan makanan kariogenik tertinggi kedua setelah snack adalah pola makan roti, yaitu 43,90\% yang dikonsumsi satu kali sehari oleh 18 anak. Hal ini dapat disebabkan roti banyak dikonsumsi karena sangat praktis untuk bekal diantara waktu makan, ditambah lagi saat ini roti memiliki variasi yang lebih beragam serta mudah didapat. Roti merupakan jenis makanan basah yang bertekstur lunak sebagai sumber karbohidrat. Seiring dengan berjalannya waktu, roti tidak lagi dinikmati di pagi hari saja, tetapi sudah meluas sebagai menu makanan alternatif pada siang hari dan malam hari disegala kondisi dan waktu makan. ${ }^{13}$

Persentase pola makan makanan kariogenik tertinggi ketiga setelah roti adalah pola makan permen, yaitu 41,46\% yang dikonsumsi lebih dari tiga kali sehari oleh 17 anak. Hal ini dapat disebabkan permen adalah salah satu jenis makanan kariogenik yang paling sering dikonsumsi dan disukai oleh anak - anak (hampir dikonsumsi setiap hari), apalagi kini permen mempunyai aneka cita rasa maupun bentuk yang menarik. Permen dibuat dengan cara mendidihkan campuran gula dan air bersama dengan zat pewarna dan pemberi rasa sampai tercapai kadar air kira - kira 3\%. Gula yang di tambahkan pada pembuatan permen sekitar 5,35\%. Disamping seringnya konsumsi permen, bentuknya yang lama melekat pada gigi menyebabkan permen bersifat sangat kariogenik. ${ }^{9}$

Persentase pola makan makanan non kariogenik tertinggi pertama terdapat pada pola makan nasi dengan frekuensi 2-3 kali sehari yaitu 70,73\% dengan jumlah 29 anak. Hal ini disebabkan nasi merupakan sumber utama energi dalam hidangan di Indonesia. Bahan makanan pokok bagi sebagian besar masyarakat Indonesia ini banyak dimanfaatkan sebagai sumber karbohidrat tubuh. ${ }^{14}$ Daerah dengan pola pangan pokok beras (nasi) biasanya belum puas atau mengatakan belum makan apabila belum makan nasi, meskipun perut sudah kenyang oleh makanan lain nonberas. ${ }^{15}$ Persentase pola makan makanan non kariogenik tertinggi kedua 
terdapat pada pola makan sayuran dengan frekuensi pola makan $2-3$ kali sehari, yaitu sebesar $48,78 \%$. Hal ini disebabkan warga di sekitar SDN Cikawari Kabupaten Bandung memiliki mata pencaharian berkebun berupa sayuran serta letaknya di dataran tinggi. Hasil panen perkebunan inilah yang digunakan oleh warga sekitar sebagai sumber makanan dalam memenuhi kebutuhan pangan.

Persentase pola makan makanan non kariogenik tertinggi ketiga terdapat pada pola makan mie instan dengan frekuensi satu kali sehari, yaitu sebesar 43,90\%. Hal ini dimungkinkan karena mie (khususnya mie instan), sebagai makanan olahan dari gandum atau terigu tersebut, dapat diolah dengan mudah, disajikan secara praktis, dan memenuhi selera berbagai kelompok masyarakat berdasarkan tingkat pendapatan, pekerjaan, usia, maupun jenis kelamin. Promosi mie yang sangat intensif dalam berbagai jenis produk, bentuk, ukuran, dan harga yang relatif murah, menyebabkan mie (khususnya mie instan) mudah dan cepat dikenal masyarakat. Mie instan telah menggeser peranan makanan pokok tradisional (jagung, ubi kayu, ubi jalar, dan sagu) sebagai makanan pokok kedua setelah beras. ${ }^{16}$

Hasil penelitian mengenai pengalaman karies pada anak SDN Cikawari Kabupaten Bandung menunjukkan rerata indeks DMF-T usia 11-12 tahun yang dimiliki oleh 41 subjek penelitian adalah 3,95 yang termasuk dalam kategori sedang. Komponen D untuk decay memiliki jumlah paling tinggi yaitu 161, sedangkan komponen missing berjumlah 1 dan untuk gigi yang ditambal karena karies (filling) tidak satupun terdapat pada subjek penelitian. Sama halnya dengan penelitian yang dilakukan oleh Worotitjan dkk tahun 2013 yang dilakukan pada anak kelas VI SD di desa Kiawa Kecamatan Kawangkoan Utara dengan rerata indeks DMF-T 3,47 yang juga masuk dalam kategori sedang. ${ }^{8}$ Begitu juga dengan hasil penelitian oleh Wala, dkk, tahun 2014 pada 54 anak yang berusia 11-12 tahun pada keluarga pemegang Jamkesmas di Kelurahan Tumatangtang I, Kecamatan Tomohon Selatan, dengan indeks DMF-T rerata 3,8 yang merupakan kategori status karies sedang. ${ }^{17}$

Penyakit gigi dan mulut yang paling banyak terjadi adalah karies gigi). Karies merupakan suatu penyakit infeksi yang mempengaruhi jaringan keras gigi, yaitu email, dentin dan sementum yang disebabkan oleh aktifitas mikroorganisme dalam suatu karbohidrat yang dapat difermentasikan. Terjadinya karies tidak hanya disebabkan oleh 4 etiologi utama, yaitu host, mikroorganisme, waktu dan substrat. Faktor risiko karies pun memegang peran penting dalam tingkat keparahan karies, seperti jenis kelamin, usia, status sosial ekonomi, kebiasaan menjaga kebersihan gigi dan mulut, serta pola makan. ${ }^{4}$

Berdasarkan informasi yang didapatkan peneliti dari wawancara singkat pada pihak sekolah, orangtua, maupun anak, pihak sekolah belum melaksanakan program UKGS, serta di Kampung Cikawari, khususnya di SDN Cikawari Kabupaten Bandung belum pernah diadakan penyuluhan mengenai kesehatan gigi dan mulut. Kurangnya pengetahuan anak mengenai kesehatan gigi mempengaruhi mereka dalam membersihkan gigi, ditambah dengan keadaan sosial ekonomi warga yang tinggal di sekitar SDN Cikawari Kabupaten Bandung tergolong menengah kebawah, transportasi menuju kota tidak memadai, serta sulitnya medan yang dilalui karena letak geografisnya di dataran tinggi memperkuat alasan untuk tidak memeriksakan gigi dan mulut ke dokter gigi.

Berdasarkan hasil penelitian, sebagian besar anak SDN Cikawari memiliki pola makan makanan kariogenik (46,13\%). Makanan kariogenik memiliki kandungan karbohidrat yang tinggi, salah satunya adalah sukrosa. Sukrosa memiliki tingkatkariogenitas paling tinggi diantara substrat karbohidrat lainnya. Sukrosa dari sisa makanan pada gigi dalam jangka waktu tertentu akan menyebabkan timbulnya asam yang dihasilkan oleh mikroorganisme, terutama Streptococcus mutans, yang akan menurunkan $\mathrm{pH}$ mulut menjadi kritis yaitu kurang dari 5,5. Hal ini akan menyebabkan terjadinya demineralisasi email dan akan berlanjut menjadi karies gigi. Faktor yang juga mempengaruhi proses terjadinya karies adalah frekuensi dan waktu konsumsi makanan yang mengandung karbohidrat. Waktu memegang peranan penting dalam proses terjadinya karies. Hal ini disebabkan pada saat jam pelajaran di sekolah aktivitas produksi saliva menurun, sehingga makanan dan minuman yang mengandung karbohidrat yang dikonsumsi pada saat istirahat akan mudah melekat pada permukaan gigi. Keadaan ini akan menyebabkan terjadinya karies gigi. ${ }^{4}$

Berdasarkan Tabel 4, pola makan makanan non kariogenik juga memiliki persentase yang juga tinggi dibandingkan pola makan makanan kariogenik, yaitu 70,73\%. Pola makan sayuran yang merupakan salah satu jenis makanan non kariogenik 
merupakan persentase tertinggi pada penelitian ini. Sayuran kaya akan vitamin, mineral dan air serta mengandung serat yang dapat merangsang fungsi pengunyahan dan sekresi saliva, akibatnya membantu melancarkan pembersihan sendiri pada gigi, mengurangi luas permukaan plak, dan pada akhirnya karies gigi dapat dicegah. ${ }^{4}$

Hasil penelitian ini menunjukkan bahwa salah satu penyebab pengalaman karies pada subjek penelitian termasuk dalam kategori sedang adalah tingginya persentase pola makan makanan kariogenik diimbangi dengan persentase pola makan makanan non kariogenik yang tinggi juga. Hal ini menjelaskan bahwa apabila konsumsi makanan kariogenik seseorang tinggi namun diimbangi dengan konsumsi makanan non kariogenik yang tinggi juga, maka tingkat keparahan karies juga tidak akan terlalu tinggi bahkan dapat rendah.

Berdasarkan penelitian mengenai distribusi pola makan makanan kariogenik dan non kariogenik serta pengalaman karies pada anak usia 11-12 tahun di SDN Cikawari Kabupaten Bandung maka terdapat hal-hal yang perlu disarankan sebagai berikut: (1) perlu dilakukan penyuluhan mengenai makanan yang baik dan buruk untuk kesehatan gigi dan mulut pada seluruh siswa SDN Cikawari Kabupaten Bandung; (2) siswa-disarankan untuk menjaga kesehatan gigi dan mulut dengan mengurangi makan makanan kariogenik yang dapat merusak gigi; (3) perlu diadakan penyuluhan mengenai cara menjaga kesehatan gigi dan mulut sebagai tindakan pencegahan karies; (4) pihak sekolah diharapkan dapat melaksanakan program UKGS untuk pemeliharaan kesehatan gigi dan mulut siswa SDN Cikawari Kabupaten Bandung; serta (5) perlu dilakukannya analisis hasil penelitian lebih lanjut mengenai hubungan antara pola makan makanan kariogenik dan non kariogenik dengan pengalaman karies. Hasil penelitian ini diharapkan dapat digunakan sebagai bahan acuan dan masukan untuk menyusun kebijakan pemerintah lebih lanjut terkait upaya peningkatan kesehatan gigi dan mulut.

\section{SIMPULAN}

Distribusi pola makan makanan kariogenik dan non kariogenik serta pengalaman karies pada anak SDN Cikawari Kabupaten Bandung, maka dapat ditarik simpulan sebagai berikut, pola makan makanan kariogenik tertinggi pada anak usia 11-12 tahun di
SDN Cikawari Kabupaten Bandung adalah snack, roti dan permen sedangkan pola makan makanan non kariogenik tertinggi adalah nasi, sayuran dan mie instan. Anak usia 11-12 tahun di SDN Cikawari Kabupaten Bandung memiliki pengalaman karies yang termasuk dalam kategori sedang berdasarkan rerata indeks DMF-T.

\section{DAFTAR PUSTAKA}

1. Fikawati S, Syafiq A, Veratamala A. Gizi anak dan remaja. $1^{\text {st }}$ ed, cetakan ke-1. Depok: Rajawali Pers. 2017. h. 71-106.

2. Kartikasari HY. Hubungan konsumsi makanan kariogenik dengan kejadian karies gigi dan status gizi pada anak kelas III dan IV SDN Kadipaten I dan II Kabupaten Bojonegoro. Semarang: Universitas Diponegoro. J Nutrition College 2014:3(3):414-21. DOI: 10.14710/jnc. v3i3.6605.

3. Judarwanto W. Perilaku makan anak sekolah. Jakarta: direktorat bina gizi kementrian kesehatan Republik Indonesia. 2011. h. 1-4.

4. McDonald RE, Avery DR, Dean JA. Dentistry for the Child and Adolescent. $8^{\text {th }}$ Ed. St. Louis: Mosby. 2009. h. 203-35.

5. Sumini $A B$, Nurhayati D. Hubungan konsumsi makanan manis dengan kejadian karies gigi pada anak prasekolah di TK B RA Muslimat PSM Tegalrejo, DesaSemen, Kecamatan Nguntoronadi, Kabupaten Magetan. J Delima Harapan 2014;30: 20-7.

6. Rosidi A, Haryani S, Adimayanti E. Hubungan antara konsumsi makanan kariogenik dengan kejadian karies gigi pada anak SDN 1 Gogodalem Kecamatan Bringin, Kab Semarang. Prosiding Seminar Nasional \& Internasional. 2014. h. 1-7.

7. Badan Penelitian dan Pengembangan Kesehatan Kementerian Kesehatan RI. RISKESDAS. Tahun 2013. Jakarta: Kemenkes RI. 2013. h. 76-141.

8. Indry W, Mintjelungan CN, Paulina G. Pengalaman karies gigi serta pola makan dan minum pada anak sekolah dasar di Desa Kiawa, Kecamatan Kawangkoan Utara. J e-GiGi (eG) Maret 2013; 1(1):59-68.

9. Hidayanti L. Hubungan karakteristik keluarga dan kebiasaan konsumsi makanan kariogenik dengan keparahan karies gigi anak sekolah dasar: Survei pada Anak Sekolah Dasar di Kecamatan Cihideung, Kota Tasikmalaya (Tesis). Semarang: 
Universitas Diponegoro. 2005. h. 1-13.

10. Desmita EI. Psikologi perkembangan. Bandung: PT Remaja Rosdakarya. 2012.

11. Djarwanto. Statistik sosial ekonomi. $2^{\text {nd }} E d$. Yogyakarta: BPFE. 1998.

12. Irianto K. Gizi dan pola hidup sehat. Bandung: yrama widya. 2007.

13. Irmawati N. Konsep bauran pemasaran pada roti goreng coklat mini. Jember: Universitas Jember. 2012.

14. Hawkins RJ. Oral hygiene knowledge of high risk grade one children: an evaluation of two methods of dental health education. J community
Dentistry and Epidemiology. 2000;28:336-43.

15. Khumaidi, M. Gizi Masyarakat. Jakarta: BPK Gunung Mulia. 1994.

16. Rochmawati, Marlenywati. Perilaku konsumsi mie instan mahasiswa fakultas ilmu kesehatan universitas muhammadiyah dan jurusan gizi Poltekkes Kemenkes Pontianak. J Vokasi Kes November 2015;I(6):188-194.

17. Wala HC, Wicaksono DA, Tambunan E. Gambaran Status Karies Gigi Anak Usia 11-12 tahun pada Keluarga Pemegang Jamkesmas di Kelurahan Tumatangtang I Kecamatan Tomohon Selatan. Jurnal e-Gigi PAAI. 2014. Vol 2. No 1. Hal: 1-8. 